\title{
AN ASSESSMENT OF THE INTENTION TO ACCEPT THE SHARIAH-COMPLIANT CROWDFUNDING MODE OF FINANCING IN BORNO STATE, NIGERIA
}

\author{
Sagir Muhammad Sulaiman ${ }^{1}$, Yusuf Muhammad² and Muhammad Abdulaziz \\ Muhammad $^{3}$ \\ ${ }^{1}$ IIIBF, Bayero University Kano, Nigeria, sageeerala@gmail.com \\ 2 IIIBF, Bayero University Kano, Nigeria, algadawy642@gmail.com \\ ${ }^{3}$ SAAL Research Consultancy Kano, Nigeria, mamhus30@gmail.com
}

\begin{abstract}
Micro-, small and medium-sized enterprises (MSMEs) face numerous obstacles, such as a lack of funding, which hinder their growth and expansion. They must have access to long-term funding to improve and modernise their operations competitively. This study aims to incorporate Shariah-compliant crowd funding among MSMEs in Borno state in Nigeria. It applies partial least squares structural equation modelling (PLSSEM) on a sample of 341 MSMEs and recommends the need to educate and enlighten them about the benefits of Islamic crowdfunding. The study also recommends the need to produce guidelines that will help develop a legal and regulatory framework for the incorporation of crowdfunding into corporate financing structures. Finally, it is recommended that religious leaders at various levels organise educational programmes on the importance of Shariah-compliant crowdfunding.
\end{abstract}

Keywords: Crowdfunding, Shariah-compliant, Theory of planned behaviour.

JEL classification: Z12; G20; G41.

Article history:

Received : October 7, 2020

Revised : May 3, 2021

Accepted : June 24, 2021

Available online : November 30, 2021

https://doi.org/10.21098/jimf.v7i4.1271 


\section{INTRODUCTION}

\subsection{Background}

The coming together of two or more financial donors to support a particular project or idea is called crowdfunding (Belleflamme, Lambert \& Schwienbacher, 2014). It is a concept that entails varying forms of raising funds and is a situation in which groups of individuals pool or gather money, usually consisting of very small contributions, to support or achieve a particular goal. The mechanisms and dynamics of Islamic crowdfunding in particular, and crowdfunding in general, are not yet well understood, even though there have been increased efforts from relevant policymakers, regulators, investors, and founders to do so (Griffin, 2012).

Crowdfunding originated from the concept of crowdsourcing, which signifies the dependence on crowds for ideas, feedback, and solutions to corporate problems (Howe, 2008). The primary objective of crowdfunding is the collection and gathering of money from the public for the development of a business or social activities that are facilitated through social network platforms. This innovative method of soliciting funding encourages entrepreneurs to source money from a large group of donors instead of significant small groups. Trust is the backbone of crowdfunding, which usually operates differently across societies and geographical locations. Therefore, trust is relatively scarce in all aspects of life particularly in businesses, hence, making it relatively hard for this financing innovation to resist the test of time (Soreh, 2017).

According to Mollick \& Robb (2016), fund raising and transactions take place on online or offline platforms. Online fund raising takes place on special crowdfunding websites, usually in collaboration with social networking platforms or websites. On the other hand, offline fund raising is conducted in a particular geographical area or location, such as crowd points and shops. These avenues initiate mode of operation as well as regulating transactional activities; i.e., legal and regulatory frameworks of how to process financial transactions.

Crowdfunding in the form of donations, rewards, debt and equity represents a new mode of financing for entrepreneurial activities and small enterprises, overcoming the funding gap and risk implications faced by financial institutions. The equity form of crowdfunding has been gaining momentum as an alternative source of finance for entrepreneurs, especially for start-ups. The number of transactions has been increasing every year since 2009. In 2011, start-up entrepreneurs worldwide raised $\$ 88$ million via equity crowd funding platforms (Crowd Funding Industry, 2012).

Islamic finance needs to devise alternatives to traditional banking that will serve as channels to empower entrepreneurs. This is because the majority of Muslim countries, especially in the African sub region, are at the development stage. Therefore, Islamic finance, by acting as an alternative and ethical financing method, should finance impact-oriented real economic activities (Asutay, 2007, 2012). Shariah-compliant crowdfunding provides the opportunity for MSME donors and investors to achieve socioeconomic development with the prohibition of all forms of usury/interest (Riba) based transactions. Financing should be related to the real sector of the economy by observing the principles of risk and profit sharing. 
The high demand for the development of non-banking Islamic financial institutions to cater for the financing needs of society, especially micro, small and medium-sized enterprises (MSMEs) is of paramount importance in Nigeria. Crowdfunding provides the opportunity that traditional banking is not able to offer due to its democratic access to sources of financing needed through its network (Mollick \& Robb, 2016). Crowdfunding, as a platform for financing MSME businesses and innovative ideas, is gaining momentum in the USA, Canada, and Europe, but the concept is relatively new in Nigeria.

MSME businesses are the bedrock of any nation's industrialisation, especially in a developing country such as Nigeria. The role of MSMEs as an engine for economic growth and development has attracted considerable public attention. Carpenter (2015) and Kalanje (2016) are of the view that MSMEs contribute significantly to the Nigerian economy and development, constituting ownership of $10 \%$ of manufacturing companies and $70 \%$ in terms of employment generation. In the same vein, Owualah (2017) reveals that MSMEs were able to produce $40 \%$ of the country's output and also accounted for $30 \%$ of the value added in the manufacturing sector.

Borno state is located in the north-east region in Nigeria and occupies the greater part of the Chad Basin. It shares boundaries with Adamawa state to the south, Gombe state to the west and Yobe state to the north west. The state is dominated by the Muslim Kanuri ethnic group. It has significant agricultural, industrial, manufacturing, trade and marketing, and communications potential, together with other resources including a landmass of around 70,898 square metres that provides huge economic potential for reducing poverty.

The World Bank (2016) indicates that only 14\% of MSMEs had access to bank loans or overdraft protection in Nigeria. Similarly, Ariyo (2015) identifies some of the bottlenecks faced by the indigenous MSMEs, including gaining access to bank credit, lack of collateral, and lack of awareness. The major problem that affects the operation of businesses in Borno state is financial constraint. The government is making some efforts to progress into an agro-industrial economy in order to achieve economic diversification, employment creation and income generation, thus promoting growth of the economy and alleviating hunger and poverty.

\subsection{Objective}

The objective of the research is to determine the extent to which attitude, subjective norms, perceived behavioural control and religiosity influence the intention to accept the Shariah-compliant crowdfunding mode of financing. It also aims to establish the moderating effect of gender on the endogenous and exogenous constructs among MSMEs in Borno state. The research consists of five sections. The first section introduces the paper, with both theoretical and empirical previous studies reviewed in section two. Section three discusses the methodology; the data analysis and presentation are explained in section four; and finally, section five comprises the conclusion, recommendations and frontier for further studies. 


\section{LITERATURE REVIEW}

\subsection{Background Theory}

Generally, the literature documents three key theories which are popular in the study of intention. The first is the Technology Acceptance Model (TAM) of Davis et al. (1989), secondly Theory of Reasoned Action (TRA) and lastly Theory of Planned Behaviour (TPB). The TRA has been criticised on the grounds that it is applicable only to behaviour under volitional control. It is for this reason that Ajzen (1985) added an additional construct, behavioural control, in the prediction of behaviour beyond volitional control. He called the theory the theory of planned behaviour (TPB). It is argued that activities usually undertaken willingly (or unwillingly) are sometimes subject to the influence of factors other than those under one's control (Ajzen \& Madden, 1986). Hence the theory proposes that apart from the behavioural and normative beliefs which determine attitude and subjective norms, certain beliefs about resources and opportunities also determine what is known as perceived behavioural control. These control beliefs can thus be treated as independent predictors of behaviour.

Husin, Haron, \& Aziz (2020) adopted the technology acceptance model (TAM); a study of Sulaeman and Ninglasari (2020) adopted the unified theory of acceptance and use of technology (UTAUT) Model; Islam and Khan (2020) employed the grounded theory (GT) approach; Islam and Khan (2019) used the UTAUT model, and lastly Thaker (2018) employed the TAM.

Perceived behavioural control is a person's perception of how difficult or easy the display of behaviour would be and is reflective of past behaviour and anticipated impediments (Beck \& Ajzen, 1991). The theory of planned behaviour involves two versions. The first is the case in which perceived behavioural control is mediated by intention in its effect on actual behaviour, while the second is the case in which actual behaviour is directly influenced by perceived behavioural control without the mediating effect of intention. However, for case two to hold, certain requirements need to be met. First, the behaviour under investigation must be partly determined by factors not under a person's control, and second, perceived behavioural control must to some degree be realistic (Ajzen \& Madden, 1986). This study adapted the theory of planned behaviour by adding religiosity as an independent variable that influences the intention to accept Shariah-compliant crowdfunding.

\subsection{Previous Studies}

Husin, Haron \& Aziz (2020) report that perceived ease of use significantly influences perceived usefulness, and that the relationship between perceived ease of use and intention is mediated by the perceived usefulness of Islamic crowdfunding in small and medium-sized enterprises. Therefore, there is a need to include micro enterprises, as their opinion of Islamic crowdfunding is also important.

Sulaeman \& Ninglasari (2020) examined the behavioural intentions of Muslim crowd funders by using a Zakat-based crowdfunding platform model. Their findings show that all the study variables, excluding facilitating conditions, had a significant positive impact on the intention of Muslim crowd funders to use the Zakat-based crowdfunding platform model. However, their study establishes a 
direct relationship, so there is a need to include a mediator or moderating variable in order to examine the indirect effect or strengths and weaknesses of the model employed.

Islam \& Khan (2020) empirically explored the reasons behind thenon-acceptance by entrepreneurs of crowdfunding. Their results indicate five barriers or reasons responsible for such unacceptability, namely the absence of crowdfunding knowhow, scarcity of government support, vulnerability of security, risk of reputation and unfavourable nature of crowdfunding. The absence of crowdfunding knowhow is the most significant concern for entrepreneurs. The outcome of the study provides a unique conceptualisation of the determinants of crowdfunding and can be used as a guide to effectively design crowdfunding and start-up fostering strategies. However, the study suffers from methodological weaknesses; that is, it employs a non-parametric approach and is applied to conventional crowdfunding. Similar studies on Islamic crowdfunding could be conducted by employing a more robust methodology.

Baber (2020) aimed to investigate the influence of FinTech applications and crowdfunding on customer retention among customers of Islamic banks in Malaysia and the United Arab Emirates. The results show that the financing application of FinTech has no relevance to customer retention, while on the other hand variables such as payments, advisory services, compliance and crowdfunding have a significant positive influence on retaining customers in the two countries. Islam \& Khan (2019) aimed to identify the motivation behind the intentions of entrepreneurs to adopt crowdfunding in Bangladesh. Their results indicate that performance expectancy, effort expectancy, social influence, facilitating conditions and perceived trust significantly influence entrepreneurs' behavioural intention to adopt it. However, trialability has a significant positive relation with use behaviour or actual use.

Thaker (2018) modelled MSMEs' behavioural intention to adopt Islamic crowdfunding Small and Medium-Sized Enterprises (ICMSMEs) model as a source of financing in Malaysia. The findings of the study reveal that both perceived usefulness and perceived easy to use significantly influenced the intention of MSMEs to use the ICMSME model, which subsequently helps in gaining access to financial services in Malaysia. Furthermore, perceived ease to use also has a positive and direct effect on the perceived usefulness of MSMEs' use of the ICMSME model.

Research conducted by Oseni (2017) examined the importance of crowdfunding for SMEs as alternative source of financing. The work also empirically assesses the specific financial needs of SME halal firms, and critically evaluates the legal and regulatory framework for equity crowdfunding, subsequently providing a Shariahcompliant-based equity crowdfunding model that suits the Islamic financial services industry. Soreh (2017), in a study of Nigeria, reveals low participation in crowdfunding, with only $2.2 \%$ patronage and no cases of participation as fundraisers. This signifies a significant gap between crowdfunding awareness and actual participation. The study concludes that crowdfunding has all the potential to support entrepreneurial activities in Nigeria. Hence, there is need for relevant regulatory bodies to play a role in changing the attitude of people toward the concept of crowdfunding in Nigeria in order to benefit from its funding innovation. 
The study was of awareness of and attitudes towards crowdfunding in general and only covered three cities. Therefore, there is need to conduct similar studies in other parts of Nigeria, especially in areas where MSMEs are facing serious challenges to access to finance, by measuring the intention to specifically accept or adopt Shariah-compliant crowdfunding as an alternative to traditional banking in term of financing.

Ajibade (2016) studied crowdfunding in Nigeria and found that such activities in Nigeria had to be suspended due to legal challenges (Securities and Exchange Commission, 2016). The reason behind the suspension was that the capital market regulations and laws, i.e. the Investment and Securities Act (ISA, 2007) and the Companies and Allied Matters Act (CAMA, 1990) did not recognise crowdfunding financial activities, so did not make provisions for them. The findings reveal that the Nigerian Securities and Exchange Commission (SEC) can adopt and adapt legal and regulatory rulings from countries such as Canada, the UK and the USA to fit its own context. However, this paves the way to empirically test the intention to accept crowdfunding in general and Shariah-compliant crowdfunding in particular as alternative forms of financing.

\section{METHODOLOGY}

\subsection{Data}

The population consisted of entrepreneurs in the Biu and Mirnga markets, who were located in Biu local government, totalling 3450 entrepreneurs (Bukar, 2015). In line with Krejcie and Morgan (1970) table for determining sample size, the study arrived at 341 sample. The study adopted a quantitative research design. The idea behind the survey design was to measure the variables by presenting a set of statements on the relationships between the constructs (Isah, 2010). The target population in the study were MSMEs who were residents of Biu local government area of Borno state; purposive sampling techniques were adopted to capture the target respondents proportionately in the two markets. The data were collected between March and June 2019. A total of 341 copies of the questionnaire were distributed and after follow up 319 were returned, representing a response rate of $94 \%$.

Table 1.

Study Variables

\begin{tabular}{|c|c|c|}
\hline Code & $\begin{array}{l}\text { Intention } \\
\end{array}$ & Sources \\
\hline ITN1 & $\begin{array}{l}\text { I am interested in accepting Shariah-compliant } \\
\text { crowdfunding for poverty alleviation }\end{array}$ & $\begin{array}{l}\text { Ajzen (1985), Ajzen (2012), Ajzen and } \\
\text { Fishbein (1980), Perdana et al. (2018) }\end{array}$ \\
\hline ITN2 & $\begin{array}{c}\text { I am interested in accepting Shariah-compliant } \\
\text { crowdfunding because of its feature of being } \\
\text { interest free (Riba) }\end{array}$ & $\begin{array}{l}\text { Ajzen (1985), Ajzen (2012), Ajzen and } \\
\text { Fishbein (1980), Perdana et al. (2018) }\end{array}$ \\
\hline ITN3 & $\begin{array}{l}\text { I think more people would accept Shariah- } \\
\text { compliant crowdfunding for poverty alleviation }\end{array}$ & $\begin{array}{l}\text { Ajzen (1985), Ajzen (2012), Ajzen and } \\
\text { Fishbein (1980), Perdana et al. (2018) }\end{array}$ \\
\hline ITN4 & $\begin{array}{l}\text { I think my family would accept Shariah- } \\
\text { compliant crowdfunding for poverty alleviation }\end{array}$ & $\begin{array}{l}\text { Ajzen (1985), Ajzen (2012), Ajzen and } \\
\text { Fishbein (1980), Perdana et al. (2018) }\end{array}$ \\
\hline ITN5 & $\begin{array}{l}\text { I think my friends would accept Shariah- } \\
\text { compliant crowdfunding for poverty alleviation }\end{array}$ & $\begin{array}{l}\text { Ajzen (1985), Ajzen (2012), Ajzen and } \\
\text { Fishbein (1980), Perdana et al. (2018) }\end{array}$ \\
\hline
\end{tabular}


Table 1.

Study Variables (Continued)

\begin{tabular}{|c|c|c|}
\hline Code & Intention & Sources \\
\hline Code & Attitude & \\
\hline ATT1 & $\begin{array}{l}\text { I feel that accepting Shariah-compliant } \\
\text { crowdfunding is a wise idea }\end{array}$ & $\begin{array}{l}\text { Ajzen (1985), Ajzen (2012), Ajzen and } \\
\text { Fishbein (1980), Perdana et al. (2018) }\end{array}$ \\
\hline ATT2 & $\begin{array}{l}\text { I feel that accepting Shariah-compliant } \\
\text { crowdfunding is a good idea }\end{array}$ & $\begin{array}{l}\text { Ajzen (1985), Ajzen (2012), Ajzen and } \\
\text { Fishbein (1980), Perdana et al. (2018) }\end{array}$ \\
\hline ATT3 & $\begin{array}{l}\text { I feel that by accepting Shariah-compliant } \\
\text { crowdfunding I am safe with regard to interest } \\
\text { (Riba) }\end{array}$ & $\begin{array}{l}\text { Ajzen (1985), Ajzen (2012), Ajzen and } \\
\text { Fishbein (1980), Perdana et al. (2018) }\end{array}$ \\
\hline ATT4 & $\begin{array}{l}\text { I feel that accepting Shariah-compliant } \\
\text { crowdfunding will be beneficial for me }\end{array}$ & $\begin{array}{l}\text { Ajzen (1985), Ajzen (2012), Ajzen and } \\
\text { Fishbein, (1980), Perdana et al. (2018) }\end{array}$ \\
\hline ATT5 & $\begin{array}{l}\text { I feel that by accepting Shariah-compliant } \\
\text { crowdfunding I will be more comfortable }\end{array}$ & $\begin{array}{l}\text { Ajzen (1985), Ajzen (2012), Ajzen and } \\
\text { Fishbein (1980), Perdana et al. (2018) }\end{array}$ \\
\hline Code & Subjective Norms & \\
\hline SBN1 & $\begin{array}{l}\text { Most people who are important to me would } \\
\text { think that accepting Shariah-compliant } \\
\text { crowdfunding is a wise idea }\end{array}$ & $\begin{array}{r}\text { Ajzen (1985), Ajzen (2012), Ajzen and } \\
\text { Fishbein (1980), Perdana et al. (2018) }\end{array}$ \\
\hline SBN2 & $\begin{array}{c}\text { Most people who are important to me would } \\
\text { think that I should accept Shariah-compliant } \\
\text { crowdfunding }\end{array}$ & $\begin{array}{r}\text { Ajzen (1985), Ajzen (2012), Ajzen and } \\
\text { Fishbein (1980), Perdana et al. (2018) }\end{array}$ \\
\hline SBN3 & $\begin{array}{l}\text { My family who are important to me would } \\
\text { think that accepting Shariah-compliant } \\
\text { crowdfunding is a good idea }\end{array}$ & $\begin{array}{l}\text { Ajzen (1985), Ajzen (2012), Ajzen and } \\
\text { Fishbein (1980), Perdana et al. (2018) }\end{array}$ \\
\hline SBN4 & $\begin{array}{l}\text { My friends who are important to me would } \\
\text { think that accepting Shariah-compliant } \\
\text { crowdfunding is a good idea }\end{array}$ & $\begin{array}{l}\text { Ajzen (1985), Ajzen (2012), Ajzen and } \\
\text { Fishbein (1980), Perdana et al. (2018) }\end{array}$ \\
\hline SBN5 & $\begin{array}{l}\text { My religious leaders believe that I should accept } \\
\text { Shariah-compliant crowdfunding }\end{array}$ & $\begin{array}{l}\text { Ajzen (1985), Ajzen (2012), Ajzen and } \\
\text { Fishbein (1980), Perdana et al. (2018) }\end{array}$ \\
\hline Code & Perceived Behavioural Control & \\
\hline PBC1 & $\begin{array}{l}\text { I have financial resources to engage in Shariah- } \\
\text { compliant crowdfunding }\end{array}$ & $\begin{array}{l}\text { Ajzen (1985), Ajzen (2012), Ajzen and } \\
\text { Fishbein (1980), Perdana et al. (2018) }\end{array}$ \\
\hline PBC2 & $\begin{array}{l}\text { I have the ability to engage in Shariah-compliant } \\
\text { crowdfunding }\end{array}$ & $\begin{array}{l}\text { Ajzen (1985), Ajzen (2012), Ajzen and } \\
\text { Fishbein (1980), Perdana et al. (2018) }\end{array}$ \\
\hline РBC3 & $\begin{array}{l}\text { I have enough knowledge to engage in Shariah- } \\
\text { compliant crowdfunding }\end{array}$ & $\begin{array}{l}\text { Ajzen (1985), Ajzen (2012), Ajzen and } \\
\text { Fishbein (1980), Perdana et al. (2018) }\end{array}$ \\
\hline PBC4 & $\begin{array}{l}\text { Engaging in Shariah-compliant crowdfunding is } \\
\text { within my control }\end{array}$ & $\begin{array}{l}\text { Ajzen (1985), Ajzen (2012), Ajzen and } \\
\text { Fishbein (1980), Perdana et al. (2018) }\end{array}$ \\
\hline Code & Religiosity & \\
\hline RLG1 & $\begin{array}{l}\text { My religious teaching permits me to accept } \\
\text { Shariah-compliant crowdfunding }\end{array}$ & $\begin{array}{l}\text { Ajzen (1985), Ajzen (2012), Ajzen and } \\
\text { Fishbein (1980), Perdana et al. (2018) }\end{array}$ \\
\hline RLG2 & $\begin{array}{l}\text { I believe that Shariah-compliant crowdfunding } \\
\text { does not contradict my religious teaching }\end{array}$ & $\begin{array}{l}\text { Ajzen (1985), Ajzen (2012), Ajzen and } \\
\text { Fishbein (1980), Perdana et al. (2018) }\end{array}$ \\
\hline RLG3 & $\begin{array}{l}\text { I believe that Shariah-compliant crowdfunding is } \\
\text { completely interest (Riba) free }\end{array}$ & $\begin{array}{l}\text { Ajzen (1985), Ajzen (2012), Ajzen and } \\
\text { Fishbein (1980), Perdana et al. (2018) }\end{array}$ \\
\hline RLG4 & $\begin{array}{l}\text { I believe that money generated through Shariah- } \\
\text { compliant crowdfunding can be invested in } \\
\text { halal business }\end{array}$ & $\begin{array}{l}\text { Ajzen (1985), Ajzen (2012), Ajzen and } \\
\text { Fishbein (1980), Perdana et al. (2018) }\end{array}$ \\
\hline RLG5 & $\begin{array}{l}\text { I believe that Shariah-compliant crowdfunding } \\
\text { follows Islamic principles (Shariah) }\end{array}$ & $\begin{array}{c}\text { Ajzen (1985), Ajzen (2012), Ajzen and } \\
\text { Fishbein (1980), Perdana et al. (2018) }\end{array}$ \\
\hline
\end{tabular}

Sources: Adopted from Ajzen (1985), Ajzen (2012), Ajzen and Fishbein, (1980) and Perdana et al.,(2018) 


\subsection{Model Development.}

The following hypotheses were proposed to guide the study, with reference to the studies of Ajzen (1985), Ajzen (2012), Ajzen and Fishbein (1980) and Perdana et al. (2018).

$\mathrm{H}_{\mathrm{a} 1}$ : There is a significant relationship between attitude and the intention to accept the Shariah-compliant crowdfunding mode of financing.

$\mathrm{H}_{\mathrm{a} 2}$ : There is significant relationship between subjective norm and the intention to accept the Shariah-compliant crowdfunding mode of financing.

$\mathrm{H}_{03}$ : There is significant relationship between perceived behavioural control and the intention to accept the Shariah-compliant crowdfunding mode of financing.

$\mathrm{H}_{\mathrm{a} 4}$ : There is significant relationship between religiosity and the intention to accept the Shariah-compliant crowdfunding mode of financing.

$\mathrm{H}_{\mathrm{a} 5}$ : Gender moderates the relationship between attitude and the intention to accept the Shariah-compliant crowdfunding mode of financing.

$\mathrm{H}_{\mathrm{a} 6}$ : Gender moderates the relationship between perceived behavioural control and the intention to accept the Shariah-compliant crowdfunding mode of financing.

$\mathrm{H}_{\mathrm{a} 7}$ : Gender moderates the relationship between religiosity and the intention to accept the Shariah-compliant crowdfunding mode of financing.

$\mathrm{H}_{\mathrm{a} 8}$ : Gender moderates the relationship between subjective norm and the intention to accept the Shariah-compliant crowdfunding mode of financing.

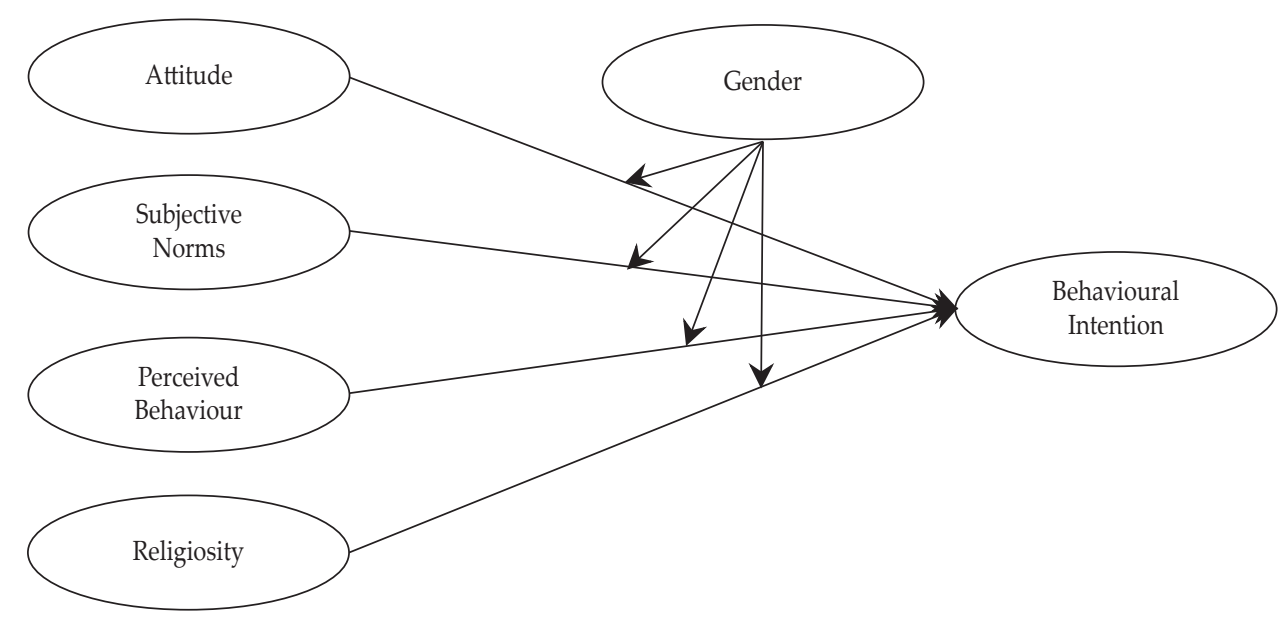

Source: Adapted from Ajzen (1991) and Perdana et al. (2018)

Figure 1.

Proposed SEM Model

\subsection{Method}

The data analysis employed PLS-SEM. The reason behind employing this technique was due to the fact that both the endogenous and exogenous variables are latent constructs in nature, i.e., measured using several indicators (Hair et al., 2010). 
PLS-SEM involves the testing of hypothesis, which requires rigorous preliminary analysis and validation, which occurs at two different stages. The first is the measurement model, whereby the individual item reliability, internal consistency reliability, and convergent and discriminant validity are assessed. The second section provides the results on the postulated hypothesis, path coefficient significance, R-squared values. The exogenous variable effect size and predictive relevance of the whole model are also reported and discussed.

\section{RESULTS AND ANALYSIS}

\subsection{Results}

\subsubsection{Demographic Information}

The survey questionnaire required respondents to answer five demographic features reflecting their gender, age group, marital status, level of education and religion. This section summarises the general frequency distribution of the respondents regarding the different demographic items, as shown in Table 2.

Table 2.

Socio-Demographic Information

\begin{tabular}{lccc}
\hline VARIABLE & Items & Frequency & Percentage \\
\hline \multirow{3}{*}{ GENDER } & Male & 287 & 90 \\
& Female & 32 & 10 \\
& Total & 319 & $\mathbf{1 0 0 . 0}$ \\
\hline \multirow{4}{*}{ AGE GROUP } & $18-29$ & 175 & 54 \\
& $30-59$ & 91 & 29 \\
& and above & 53 & 17 \\
& Total & 319 & $\mathbf{1 0 0 . 0}$ \\
\hline \multirow{3}{*}{ MARITAL STATUS } & Single & 89 & 28 \\
& Married & 187 & 59 \\
& Widow/Divorced & 43 & 13 \\
& Total & 319 & $\mathbf{1 0 0 . 0}$ \\
\hline \multirow{2}{*}{ LEVEL OF } & Primary & 41 & 13 \\
EDUCATION & Secondary & 192 & 60 \\
& Tertiary & 68 & 21 \\
& Other & 18 & 6 \\
& Total & 319 & $\mathbf{1 0 0 . 0}$ \\
\hline \multirow{2}{*}{ RELIGION } & Islam & 302 & 95 \\
& Christianity & 17 & 5 \\
& Total & 319 & $\mathbf{1 0 0 . 0}$ \\
\hline
\end{tabular}

Source: Field survey data (2019)

\subsubsection{Descriptive Analysis of the Variables}

The descriptive statistics of the study variables were also evaluated, presented and discussed. Specifically, five variables were analysed to determine their mean, standard deviation and minimum and maximum values. Table 3 provides a summary of the descriptive statistics. 
Table 3.

Descriptive Statistics of the Variables

\begin{tabular}{lccccc}
\hline \multirow{2}{*}{ Variable } & No. of & Min & Max & Mean & SD. \\
\cline { 3 - 6 } & Items & Statistic & Statistic & Statistic & Statistic \\
\hline Attitude & 5 & 1.00 & 5.00 & 4.8712 & 0.74582 \\
Subjective Norms & 5 & 1.00 & 5.00 & 4.6761 & 0.45469 \\
Perceived Behavioural Control & 4 & 1.00 & 5.00 & 3.9383 & 0.55109 \\
Religiosity & 5 & 1.00 & 5.00 & 4.2139 & 0.43258 \\
Intention & 5 & 1.00 & 5.00 & 4.7216 & 0.23258 \\
\hline
\end{tabular}

Source: Field survey (2019)

Table 3 shows that the mean and standard deviation for attitude were 4.8712 and 0.7458 respectively. This suggests that the respondents tended to have a high level of attitude. Table 3 also indicates that the mean for subjective norms was 4.6761 , with a standard deviation of 0.4547 , suggesting that the respondents' subjective norm outcomes were high. Furthermore, the results show moderate scores for perceived behavioural control (mean $=3.9383$, standard deviation $=$ 0.5511 ) and also high scores for religiosity, with mean and standard deviation of 4.2139 and 0.43258 . Finally, the mean and standard deviation of intention were 4.7216 and 0.23258 respectively.

\subsection{Evaluation of the PLS-SEM Path Model Results}

PLS-SEM is a second-generation statistical tool that involves latent variables and multiple indicators. This study used a two-step process to evaluate and report the results of the PLS-SEM path. This process comprised (1) assessment of a measurement model, and (2) assessment of a structural model, as shwon in Figure 4.1 (Hair et al., 2014; Hair et al., 2012; Henseler et al., 2009).

\subsubsection{Assessment of the Measurement Model}

In order to assess the outer model (measurement or factor model) in Smart-PLS. the measurement model is key in determining the reliability and validity of the measures used. It involves assessment of individual item reliability, the internal consistencies of the items, and convergent and discriminant validity (Henseler et al., 2009). 


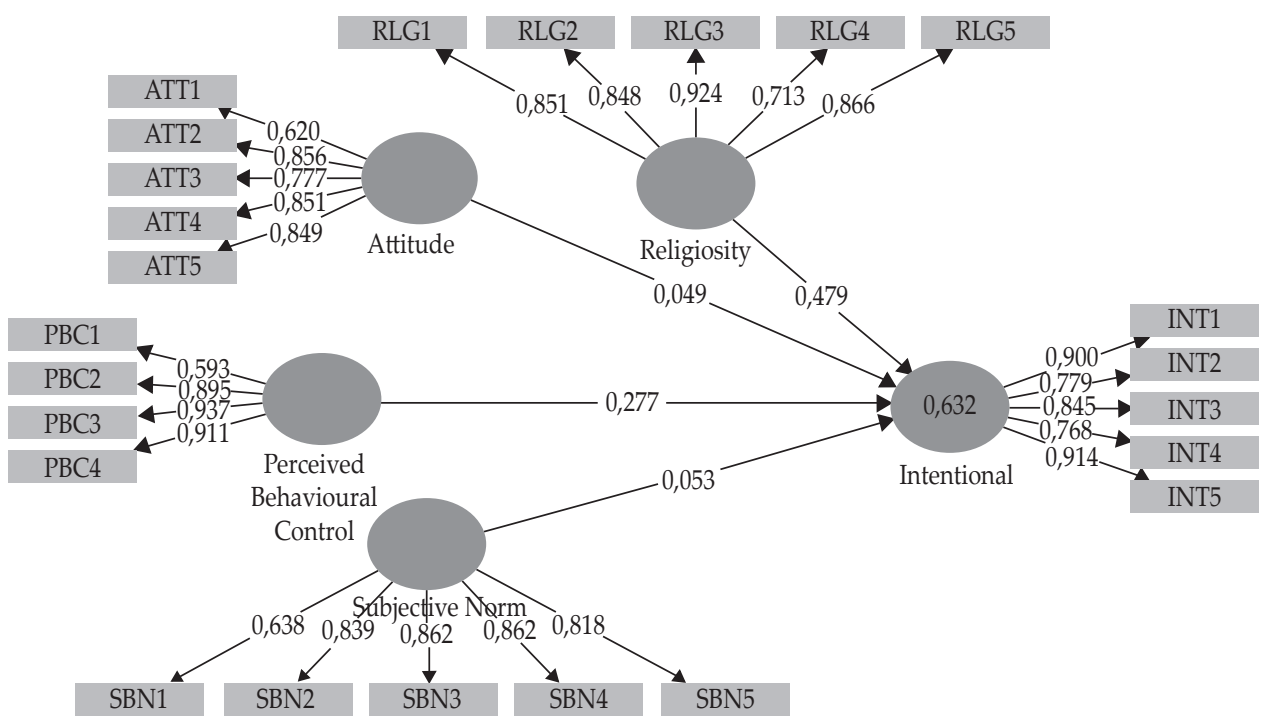

Source: Computed from the field survey (2019) using Smart-PSL 3

Figure 2.

Outer Model

\section{a. Individual Item Reliability}

This refers to the convergence of sub-items of a particular construct and is assessed by examining the outer loadings of the measure of each construct (Hair et al., 2014). Adhering to the yardstick for retaining items with loadings between 0.40 and 0.70 , out of the 24 items none were deleted because they presented loadings above the threshold of 0.40 .

\section{b. Internal Consistency}

This refers to the convergence of sub-items of a particular construct in order to measure the same construct (Bijttebier et al., 2000). In essence, composite reliability measures inter-item consistency, hence ensuring the existence of correlations among the sub-items. The most common methods of assessing internal consistency are Cronbach's alpha (Cronbach, 1951) and composite reliability (Fornell \& Larcker, 1981). Therefore, this study adopted both these to ascertain internal consistency and to dispel any doubts over the reliability of the study.

\section{c. Convergent Validity}

Convergent validity refers to the extent to which items truly represent the intended latent construct and do indeed correlate with other measures of the same latent construct (Hair et al., 2006). It was assessed by examining the average variance extracted (AVE) of each latent construct, as suggested by Fornell and Larcker (1981). 
Table 4.

Loadings, Composite Reliability and Average Variance Extracted

\begin{tabular}{|c|c|c|c|c|}
\hline & $\begin{array}{c}\text { Factor } \\
\text { Loading }\end{array}$ & $\begin{array}{c}\text { Composite } \\
\text { Reliability (CR) }\end{array}$ & $\begin{array}{l}\text { Average Variance } \\
\text { Extracted }\end{array}$ & $\begin{array}{l}\text { Cronbach's } \\
\text { Alpha }\end{array}$ \\
\hline Intention & & 0.924407 & 0.711 & 0.897 \\
\hline ITN1 & 0.899981 & & & \\
\hline ITN2 & 0.778949 & & & \\
\hline ITN3 & 0.844517 & & & \\
\hline ITN4 & 0.767891 & & & \\
\hline ITN5 & 0.913542 & & & \\
\hline Attitude & & 0.895055 & 0.633411 & 0.864 \\
\hline ATT1 & 0.62049 & & & \\
\hline ATT2 & 0.855954 & & & \\
\hline ATT3 & 0.77714 & & & \\
\hline ATT4 & 0.851203 & & & \\
\hline ATT5 & 0.849058 & & & \\
\hline Subjective Norm & & 0.903127 & 0.653 & 0.863 \\
\hline SBN1 & 0.638392 & & & \\
\hline SBN2 & 0.838659 & & & \\
\hline SBN3 & 0.8618 & & & \\
\hline SBN4 & 0.862476 & & & \\
\hline SBN5 & 0.818232 & & & \\
\hline $\begin{array}{l}\text { Perceived } \\
\text { Behavioural Control }\end{array}$ & & 0.907045 & 0.715 & 0.860 \\
\hline PBC1 & 0.592624 & & & \\
\hline РBC2 & 0.894865 & & & \\
\hline РBC3 & 0.936736 & & & \\
\hline PBC4 & 0.911259 & & & \\
\hline Religiosity & & 0.924362 & 0.711 & 0.897 \\
\hline RLG1 & 0.851216 & & & \\
\hline RLG2 & 0.848384 & & & \\
\hline RLG3 & 0.923901 & & & \\
\hline RLG4 & 0.712635 & & & \\
\hline RLG5 & 0.865745 & & & \\
\hline
\end{tabular}

Source: Field survey (2019) and computed using SPSS Version 22 and Smart-PLS 3

\section{d. Discriminant Validity}

The final type of validity of the measurement model is discriminant validity. This aims to examine the difference that exists between constructs in the study (Barclay et al., 1995). Despite aiming to explain the same thing, constructs are expected to be dissimilar, therefore sharing similarity more with its items than the other constructs. Specifically, measures of one construct are not expected to overlap in the territory of another construct. Adequate discriminant validity is achieved when a construct shares more variance than it does with other model constructs. Hence, this study adopted the work of (Fornell \& Larcker 1981). The cross loading threshold is 0.50 and above (Hair et al., 2010). However, values greater than 0.40 are also accepted. 
Table 5.

Cross Loadings

\begin{tabular}{|c|c|c|c|c|c|}
\hline & Attitude & Intention & $\begin{array}{c}\text { Perceived } \\
\text { Behavioural } \\
\text { Control }\end{array}$ & Religiosity & $\begin{array}{l}\text { Subjective } \\
\text { Norm }\end{array}$ \\
\hline ATT1 & 0.62049 & 0.136124 & 0.339661 & 0.191682 & 0.489372 \\
\hline ATT2 & 0.855954 & 0.581563 & 0.66844 & 0.537642 & 0.661042 \\
\hline ATT3 & 0.77714 & 0.331058 & 0.510919 & 0.389302 & 0.609513 \\
\hline ATT4 & 0.851203 & 0.486175 & 0.581874 & 0.482882 & 0.656968 \\
\hline ATT5 & 0.849058 & 0.378714 & 0.513493 & 0.372277 & 0.658114 \\
\hline INT1 & 0.504899 & 0.899981 & 0.696506 & 0.692879 & 0.527647 \\
\hline INT2 & 0.433213 & 0.778949 & 0.575754 & 0.589916 & 0.445678 \\
\hline INT3 & 0.401033 & 0.844517 & 0.638641 & 0.666572 & 0.441143 \\
\hline INT4 & 0.369665 & 0.767891 & 0.494551 & 0.579938 & 0.399939 \\
\hline INT5 & 0.538768 & 0.913542 & 0.728177 & 0.696525 & 0.562416 \\
\hline PBC1 & 0.629858 & 0.360896 & 0.592624 & 0.400934 & 0.719391 \\
\hline PBC2 & 0.589224 & 0.6895 & 0.894865 & 0.751586 & 0.595985 \\
\hline РBC3 & 0.60838 & 0.684173 & 0.936736 & 0.771312 & 0.630852 \\
\hline PBC4 & 0.571692 & 0.724506 & 0.911259 & 0.817795 & 0.603123 \\
\hline RLG1 & 0.554969 & 0.696338 & 0.857391 & 0.851216 & 0.577284 \\
\hline RLG2 & 0.36791 & 0.661171 & 0.6458 & 0.848384 & 0.415424 \\
\hline RLG3 & 0.549819 & 0.722315 & 0.789439 & 0.923901 & 0.585354 \\
\hline RLG4 & 0.256226 & 0.496687 & 0.472802 & 0.712635 & 0.312964 \\
\hline RLG5 & 0.480461 & 0.631475 & 0.708232 & 0.865745 & 0.500639 \\
\hline SBN1 & 0.755264 & 0.421218 & 0.511291 & 0.449326 & 0.638392 \\
\hline SBN2 & 0.567737 & 0.470908 & 0.603372 & 0.44998 & 0.838659 \\
\hline SBN3 & 0.550192 & 0.485745 & 0.621932 & 0.48397 & 0.8618 \\
\hline SBN4 & 0.631196 & 0.478352 & 0.629224 & 0.532032 & 0.862476 \\
\hline SBN5 & 0.645864 & 0.429586 & 0.536465 & 0.407677 & 0.818232 \\
\hline
\end{tabular}

Source: Field survey (2019) and computed using SPSS Version 22 and Smart-PLS 3

\subsubsection{Assessment of the Significance of the Structural Model}

Having ascertained the measurement model, the study then assessed the structural model. It applied the standard bootstrapping procedure with 1000 bootstrap samples and 391 cases to assess the significance of the path coefficients with which the structural model is concerned $\mathrm{R}^{2}$, coefficient, $\mathrm{P}$-value, predictive relevance $\left(\mathrm{Q}^{2}\right)$ and effect size $\left(\mathrm{F}^{2}\right)$, which will be explained by the structural model with the help of bootstrapping. 


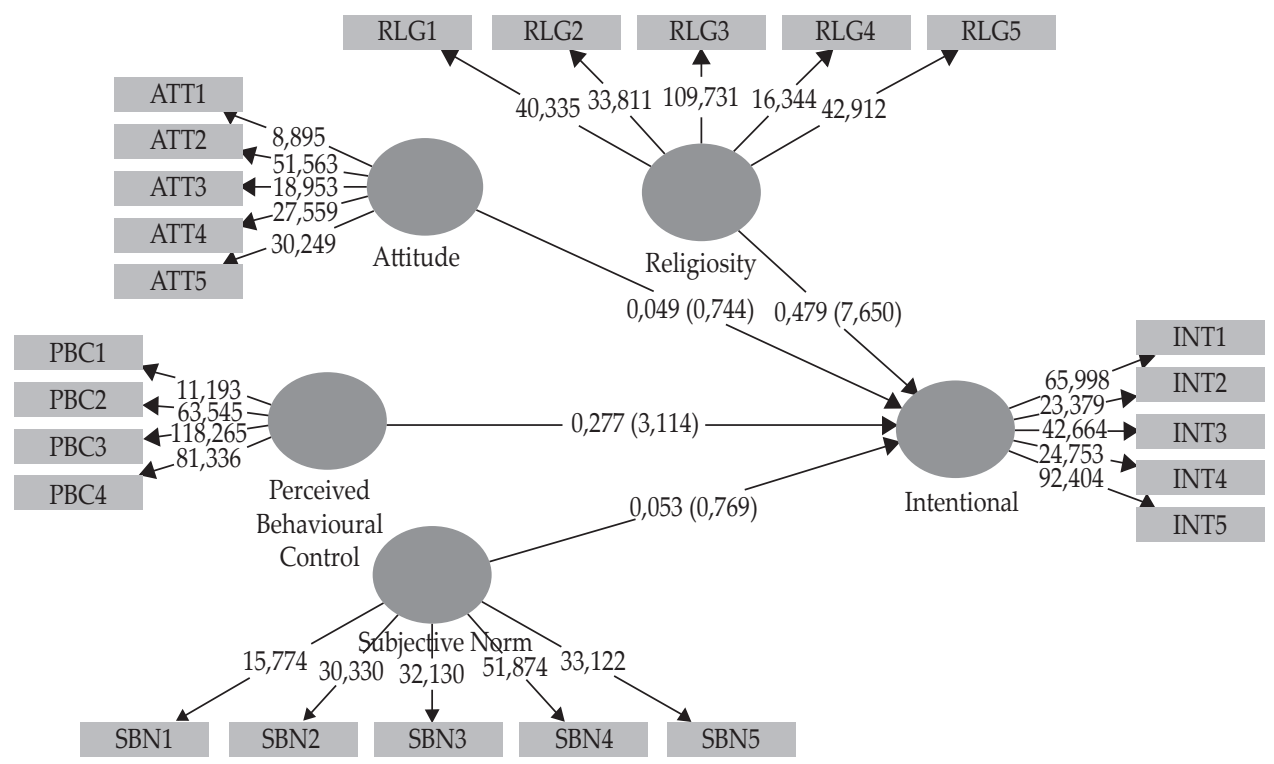

Source: Computed from field survey (2019) using Smart-PSL 3

Figure 3.

Inner Model

\section{a. Direct Relationship}

Figure 3 shows a graphical display of the standardised path coefficient $(\beta)$ and Tvalues of the study hypotheses. When a study is exploratory in nature, researchers often assume a significance level of 5\% (significance level=1.96). Table 6 shows the standardised path coefficient ( $\beta$ ), T- values and confidence intervals, as suggested by Cho and Abe (2013).

Table 6.

Results of the Direct Hypotheses

\begin{tabular}{lccccc}
\hline Hypothesis & Relationship & Beta & T-Value & P-Value & Findings \\
\hline 1 & ATT- $>$ ITN & 0.049 & 0.744 & 0.457 & Not Supported \\
2 & SBN->INT & 0.053 & 0.769 & 0.442 & Not Supported \\
3 & PBC->INT & 0.277 & 3.114 & $0.002^{* * *}$ & Supported \\
4 & RLG->INT & 0.479 & 7.650 & $0.000^{* * *}$ & Supported \\
\hline \multicolumn{2}{l}{ Note: $* * *$ Significant at the 0.01 level (two-tailed) }
\end{tabular}

Source: Field survey (2019) and computed using SPSS Version 22 and Smart-PLS 3

Hypothesis 1 proposed that attitude is positively related to intention. The result reveals an insignificant relationship between attitude and intention based on the 0.05 significance level, with a $\mathrm{t}$-value of $1.96(\beta=0.049, \mathrm{t}$-value $=0.744 \& \mathrm{p}$-value $=$ 0.457 ), so the alternative hypothesis was rejected. This finding is inconsistent with those of Oseni (2017), Thaker (2018) and Soreh (2017), who found a positive and significant relationship. 
Hypothesis 2 proposed that subjective norms are positively related to intention. The results reveal an insignificant relationship between subjective norms and intention based on the 0.05 significance level, with a t-value of $1.96(\beta=0.053$, $\mathrm{t}$-value $=0.769 \& \mathrm{p}$-value $=0.442)$, so the alternative hypothesis is rejected. This finding is inconsistent with those of Oseni (2017), Thaker (2018) and Soreh (2017).

Hypothesis 3 proposed hat perceived behavioural control is positively related to intention. The results reveal a significant and positive relationship between perceived behavioural control and intention based on the 0.05 significance level, with a t-value of $1.96(\beta=0.277$, $t$-value $=3.114 \& \mathrm{p}$-value $=0.002)$, hence the alternative hypothesis is accepted. This finding is consistent with those of Oseni (2017), Thaker (2018) and Soreh (2017).

Hypothesis four proposed in an alternative form religiosity is positively related to intention. The results reveal a significant and positive relationship between religiosity and intention based on the 0.05 significance level, with a t-value of 1.96 $(\beta=0.479, \mathrm{t}$-value $=7.650 \& \mathrm{p}$-value $=0.000)$, hence the alternative hypothesis is accepted. This finding is consistence with those of Oseni (2017), Thaker (2018) and Soreh (2017).

\section{b. Moderating effect}

Moderating or intervening variables emerge as a result of mixed findings, inconsistency or even the existence of no relationship between exogenous and endogenous constructs. Specifically, it can be deduced that moderating variables are used to strengthen, weaken or even create a relationship. Henseler \& Fassott (2010) state that "moderating effects are evoked by variables whose variation influences the strength or the direction of a relationship between an exogenous and an endogenous variable".

Henseler and Chin (2010) identified four methods of assessing moderating (interaction) effects in SmartPLS: the product indicator approach; a 2-stage approach (Chin, \& Newsted, 1999; Henseler \& Fassott, 2010); a hybrid approach (Wold, 1982); and an orthogonal approach. In this study, the product indicator method was used to evaluate, estimate and determine the moderating strength of gender on the relationship between the independent and dependent variables. Henseler and Fassott (2010) and Hair et al. (2013) recommend the use of product indicators when the moderating variable in use is a categorical or continuous one. In addition, product indicators provide better results, especially when compared with the 2-stage or orthogonal approach methods of testing moderation. In essence, an interaction is created in the dependent (endogenous) construct to indicate the moderating effect, as shown in Figure 4. 


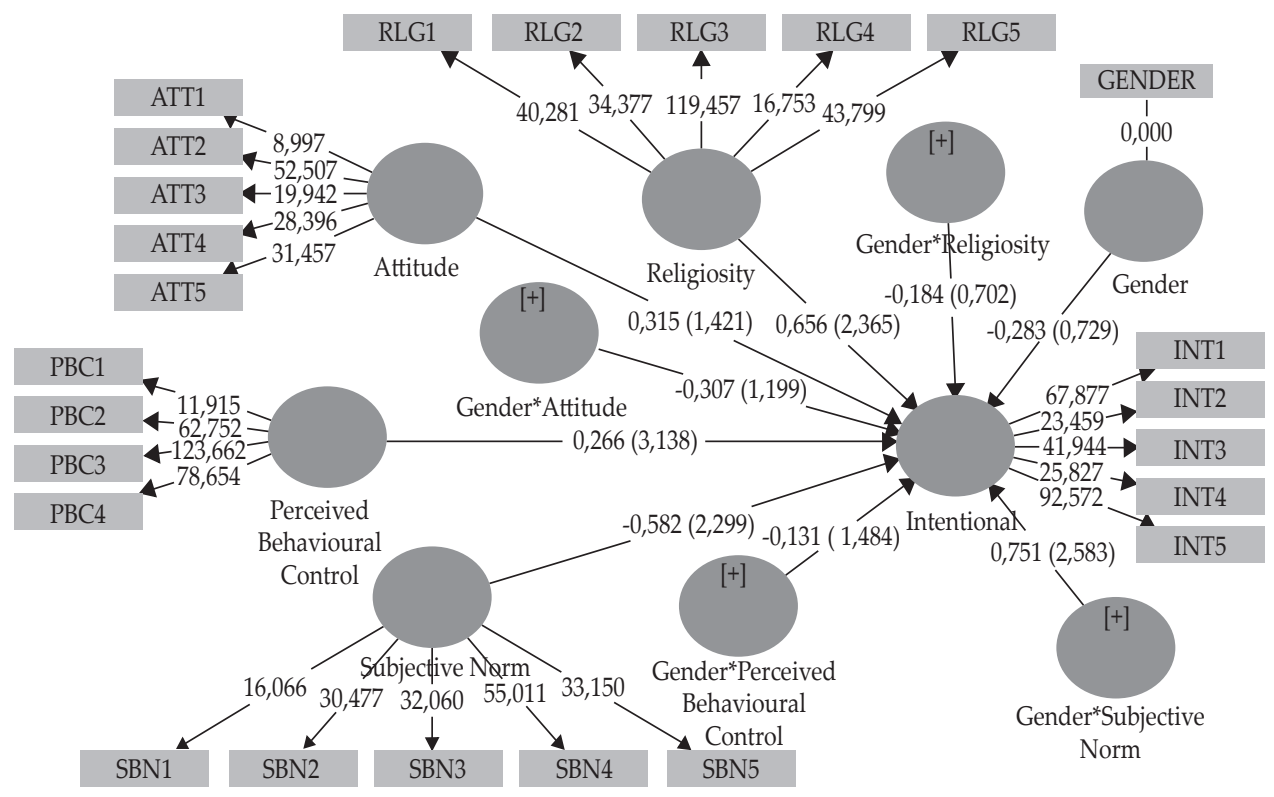

Source: Computed from field survey (2019) using Smart-PSL 3

Figure 4.

Moderation Model

Table 7.

Results of Moderation Hypothesis Test

\begin{tabular}{|c|c|c|c|c|c|}
\hline Hypothesis & Relationship & Beta & $\begin{array}{l}\text { Std. } \\
\text { Error }\end{array}$ & T-Value & P-Value \\
\hline 5 & Gender*Attitude -> Intention & -0.307 & 0.256 & 1.199 & 0.231 \\
\hline 6 & $\begin{array}{c}\text { Gender*Perceived Behavioural } \\
\text { Control -> Intention }\end{array}$ & -0.131 & 0.088 & 1.484 & 0.138 \\
\hline 7 & GenderReligiosity $->$ Intention & -0.184 & 0.261 & 0.702 & 0.483 \\
\hline 8 & $\begin{array}{c}\text { Gender*Subjective Norm -> } \\
\text { Intention }\end{array}$ & 0.751 & 0.291 & 2.583 & 0.01 \\
\hline
\end{tabular}

Source: Field survey (2019) and computed using SPSS Version 22 and Smart-PLS 3

As shown in Table 7, hypotheses 5, 6, 7 and 8 proposed that gender moderates the relationship between the exogenous variables, namely attitude, subjective norms, religiosity and perceived behavioural control and endogenous variable intention. Based on the two-interaction postulated in the study, hypotheses 5, 6 , and 7 were found to be insignificant, whereas hypothesis 8 was significant, as shown in Figure 4. From Table 7, the interaction in alternative hypothesis 8 shows that the notion that gender moderates the relationship between intention and subjective norm is accepted i.e. $(\beta=0.751$; $\mathrm{t}$-value $=2.583$; $\mathrm{p}$-value $=0.01)$. There is therefore a need to establish the disparity between male and female respondents in terms of the intention to accept Shariah-compliant crowdfunding; Figure 5 shows more detail of this. 


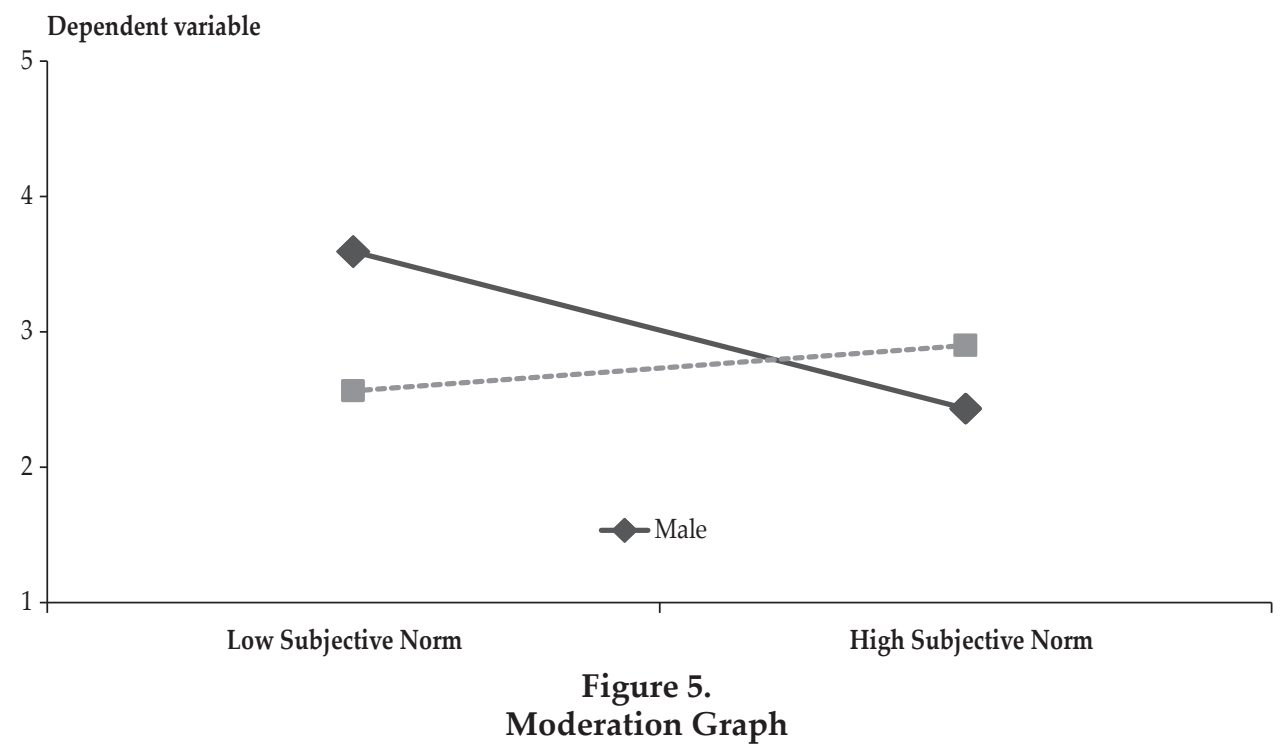

Figure 5 shows that male respondents with a low subjective norm tend to possess a high level of intention to accept Shariah-compliant crowdfunding, while on the other hand high subjective-norm male respondents had a low level of intention to accept shariah-compliant crowdfunding. In the case of female respondents with low subjective norms, their intention to accept shariah-compliant crowdfunding is low, whereas those with high subjective norms appear to have a high intention to do so.

\subsection{Assessment of the Variance Explained in the Endogenous Latent Variables}

The next step was to determine the R-squared value, which is an important part of assessing the validity of the structural model. The R-squared is also referred to as a coefficient of determination (Hair et al., 2012). The R-squared value clarifies the variance that exists in explaining endogenous variables as a result of one or two exogenous variables (Hair et al., 2010). Although the acceptable level of the $\mathrm{R}^{2}$ value depends on the research context (Hair et al., 2010), one of 0.10 is the minimum.

Table 8.

Variance Explained in the Dependent Variable

\begin{tabular}{lc}
\hline Variable & Variance Explained $\left(\mathbf{R}^{2}\right)$ \\
\hline Intention & $0.632=63.2 \%$ \\
\hline Source: Field survey (2019) and computed using SPSS Version 22and Smart-PLS 3
\end{tabular}

In predicting the dependent variable in the model, an R-square of $0.632=$ 63.2 percent was estimated, which signifies the variance in intention to accept Shariah- compliant crowd funding as explained by the exogenous variables, namely attitude, perceived behavioural control and religiosity. This is to say, other 
variables or predictors that could explain the remaining model account for 0.368 $=36.8$ percent. According to Hair et al. (2012), the acceptable threshold values for acceptance of R-squared are 0.19, 0.50 and 0.75, levels which are weak, moderate and substantial respectively.

\subsection{Assessment of Effect Size $\left(\mathrm{F}^{2}\right)$}

Having assessed and confirmed the postulated hypotheses, the next criterion for the evolution of the structural model is effect size $\left(F^{2}\right)$ (Hair et al., 2013). This indicates the relative effect of a particular exogenous latent variable on the endogenous latent variable(s) by means of changes in the R-squared (Chin, 1998). It is calculated as the increase in R-squared of the latent variable to which the path is connected, relative to the latent variable's proportion of unexplained variance (Chin, 1998), Cohen (1988) describes $\mathrm{F}^{2}$ values of $0.02,0.15$ and 0.35 as being weak, moderate, and strong respectively. Table 9 shows the respective effect sizes of the latent variables of the structural model.

Table 9.

Effect Sizes of the Latent Variables on Cohen's (1988) Recommendation

\begin{tabular}{lccc}
\hline Exogenous variable & Endogenous variable & $\mathbf{F}^{2}$ & Effect size \\
\hline Attitude & Intention & 0.002403 & No \\
Perceived Behavioural Control & Intention & 0.042139 & Weak \\
Religiosity & Intention & 0.185187 & Moderate \\
Subjective Norm & Intention & 0.002525 & No \\
\hline
\end{tabular}

Source: Field survey (2019) and computed using SPSS Version 22 and Smart-PLS 3

From the Table 9, it can be concluded that two exogenous variables, namely religiosity and perceived behavioural control, have moderate and weak effects respectively, whereas attitude and subjective norm has no effect.

\subsection{Assessment of Predictive Relevance}

Subsequent to determining the effect size or variation of the R-squared, Hair et al. (2013) recommend that predictive relevance of the model should be ascertained using Stone-Geisser's Q2 (Geisser, 1974; Stone, 1974). The process is a resampling technique by which data are systematically deleted and predicted on each of the endogenous construct's indicators (Geisser, 1974; Hair et al., 2011; Stone, 1974). In fact, predictive relevance estimates how well the study model predicts or represents omitted cases (Chin, 1998; Hair et al., 2013). The process is only beneficial for endogenous reflective constructs to ascertain their predictive relevance in the model. If the predictive relevance $\left(\mathrm{Q}^{2}\right)$ value is greater than zero, then the model has predictive relevance (Hair et al., 2013). Table 10 presents the results of the cross-validated redundancy $\mathrm{Q}^{2}$ test. 
Table 10.

$\mathrm{Q}^{2}$ or Cross-Validation Redundancy

\begin{tabular}{lccc}
\hline Total & SSO & SSE & Q2 \\
\hline Performance & 1595 & 929.5996 & 0.417178935 \\
\hline
\end{tabular}

Source: Field survey (2019) and computed using SPSS Version 22 and Smart-PLS 3

Table 10 indicates that the cross-validation redundancy result is $Q^{2}=0.4172$ for the endogenous variable, which is above zero and so signifies the predictive relevance of the model.

\section{CONCLUSION AND RECOMMENDATIONS}

\subsection{Conclusion}

The primary aim of this study was to assess the intention to accept the shariahcompliant crowdfunding mode of financing in Borno State, Nigeria. The specific objectives were to assess whether attitude, subjective norm, perceived behavioural control and religiosity have significant effects on this intention. To address this, relevant data were collected and analysed, and from the analysis results were obtained and discussed. From this discussion, the following conclusions are drawn

The predictors of the intention to accept shariah-compliant crowdfunding, namely attitude, subjective norm, perceived behavioural control and religiosity, were able to explain $0.632=63.2$ percent of the variance in such intention, while the remaining $0.368=36.8$ percent is taken care by other factors that are not stated in the model (i.e. error term).

Attitude and subjective norms have no impact on the acceptance of shariahcompliant crowdfunding, while perceived behavioural control and religiosity have a positive impact on its acceptance. Interestingly, gender only moderates the relationship between subjective norms and intention.

\subsection{Recommendation}

The study recommends that the relevant authorities develop strategies aimed at educating and enlightening MSMEs about the benefits of Islamic crowdfunding as an ethical alternative source of finance for sustainable development. It is also recommended that guidelines be developed that will help in constructing legal and regulatory frameworks for the incorporation of crowdfunding into corporate financing structures, in view of its recognition as a viable mechanism for raising funds by companies and individuals all over the world. Finally, the study recommends that religious leaders at various levels organise education programmes in masjids and other religious avenues and places of worship on the importance of the shariah-compliant crowdfunding mode of financing.

In further research, there is a need to replicate this study in different parts of Nigeria and beyond in order to compare and contrast the findings and achieve appropriate generalisation. 


\section{REFERENCES}

Ajibade, S.P.A. (2016). Crowdfunding in Nigeria. Corporate Finance; Law $\mathcal{E}$ Technology, (November 16 $\left.{ }^{\text {th }}\right), 1-6$. Retrieved from dbolu@spaajibade.com.

Ajzen, I., \& Madden, T. J (1986). Prediction of goal-directed behaviour: Attitudes, intentions, and perceived behavioral control. Journal of Experimental Social Psychology, 1(22), 453-474.

Ajzen, I. (1985). From intention to actions: A theory of planned behaviour in J. Kohl and J. Becham (Eds) Action control, pp 11-39. Heidelberg: Springers.

Ajzen, I. (1991). The theory of planned behavior. Organizational Behavior and Human Decision Processes, 50(2), 179-211.

Ajzen, I., \& Fishbein, M. (1980). Understanding attitudes and predicting social behavior. Englewood Cliffs, NJ: Prentice-Hall.

Ariyo, D. (2015). Small firms are the backbone of the Nigerian economy. African Economic Analysis, Africa Business Information Services, Bridgnorth.

Asutay, M. (2007). Conceptualisation of the second-best solution in overcoming the social failure of Islamic banking and finance: Examining the overpowering of homoislamicus by homoeconomicus. IIUM Journal of Economics and Management, 15(2), 167-195.

Asutay, M. (2012). Conceptualising and locating the social failure of Islamic finance: Aspirations of Islamic moral economy vs. the realities of Islamic finance. Journal of Asian and African Studies, 11(2), 93-113.

Barclay, D., Higgins, C., \& Thompson, R. (1995). The partial least squares (PLS) approach to causal modelling: Personal computer adoption and use as an illustration. Technology Studies, 2(2), 285-309.

Baber, H. (2020). FinTech, crowdfunding and customer retention in Islamic banks. Vision, 24(3), 260-268.

Beck, L. \& Ajzen, I. (1991). Predicting dishonest actions using the theory of planned behaviour. Journal of Research in Personality, 25(43), 285-301.

Belleflamme, P. Lambert, T., \& Schwienbacher, A. (2014) Crowdfunding: Tapping the right crowd. Journal of Business Venturing, 29(1), 585-609.

Bijttebier, P., Delva, D., Vanoost, S., Bobbaers, H., Lauwers, P., \& Vertommen, H. (2000). Reliability and validity of the critical care family needs inventory in a Dutch-speaking Belgian sample. Heart and Lung: Journal of Acute and Critical Care, 29(4), 278-286.

Bukar, U. (2015). A history of Biu. Abuja: Klamidas Communication Ltd.

Carpenter, C. (2015). SME finance in Nigeria. Round table on making small business finance profitable in Nigeria, available at http://www.ypforum.org/newscarpenter.

Chin, W. W. (1998). Commentary: Issues and opinion on structural equation modeling. MIS Quarterly, 22(1), 7-16.

Chin, W. W., \& Newsted, P. R. (1999). Structural equation modeling analysis with small samples using partial least squares. In R. H. Hoyle (Ed.), Statistical strategies for small sample research (pp. 307-341). Thousand Oaks: CA: Sage Publications.

Cho, H. C., \& Abe, S. (2013). Is two-tailed testing for directional research hypotheses tests legitimate? Journal of Business Research, 66(9), 1261- 1266.

Cohen, J. (1988). Statistical power analysis for the behavioral sciences. $2^{\text {nd }}$ edition. New York: Routledge. 
Cronbach, L. J. (1951). Coefficient alpha and the internal structure of tests. Psychometrika, 16(3), 297-334.

Crowdfunding Industry Report (2012). Crowdfunding Industry Report: Market Trends, Composition and Crowdfunding Platforms: Crowdsourcing, LLC. Department of Economics, International Islamic University Malaysia.

Davis, F.D., Bagozzi, R.P \& Warshaw, P.R (1989). User acceptance of technology: A comparison of two theoretical model. Journal of Management Science, 35(8), 34-59.

Fishbein, M., \& Ajzen, I. (1975). Belief, attitude, intention and behaviour: An introduction to theory and research. Reading, MA: Addison-Wesley.

Fornell, C., \& Larcker, D. (1981). Evaluating structural equation models with unobservable variables and measurement error. Journal of Marketing Research, 18(3), 39-50.

Geisser, S. (1974). A predictive approach to the random effect model. Biometrika, 61(1), 101-107.

Griffin, Z.J. (2012). Crowdfunding: Fleecing the American masses. Journal of Law, Technology and the internet, 4(2), 375-410.

Hair, J. F. J., Hult, G. T. M., Ringle, C., \& Sarstedt, M. (2014). A primer on 248 partial least squares structural equation modeling (PLS-SEM). LongRange planning (Vol. 46). Thousand Oaks, CA: SAGE Publications.

Hair, J. F., Black, W. C., Babin, B. J., Anderson, R. E., \& Tatham, R. L. (2010). Multivariate data analysis. $7^{\text {th }}$ Edition. Upper Saddle River: Prentice Hall.

Hair, J. F., Ringle, C. M., \& Sarstedt, M. (2013). Partial least squares structural equation modeling: Rigorous applications, better results and higher acceptance. Long Range Planning, 46(1-2), 1-12.

Hair, J. F., Sarstedt, M., Ringle, C. M., \& Mena, J. A. (2012). An assessment of the use of partial least squares structural equation modelling in marketing research. Journal of the Academy of Marketing Science, 40(3), 414-433.

Henseler, J., Ringle, C. M., \& Sinkovics, R. R. (2009). The use of partial least squares path modelling in international marketing. In Sinkovics, R.R. \& Ghauri, P.N. (Ed.) New challenges to international marketing (Advances in international marketing, Vol. 20). Emerald Group Publishing Limited, Bingley, pp. 277-319.

Henseler, J., \& Chin, W. (2010). A comparison of approaches for the analysis of interaction effects between latent variables using partial least squares path modelling. Structural Equation Modelling: A Multidisciplinary Journal, 17(1), 82-109.

Henseler, J., \& Fassott, G. (2010). Testing moderating effects in pls path models: An illustration of available procedures. In: Esposito Vinzi V., Chin W., Henseler J., Wang H. (eds). Handbook of partial least squares. Springer Handbooks of Computational Statistics. Berlin, Heidelberg: Springer.

Howe, J. (2008). Crowdsourcing. Why the power of the crowd is driving future of business. New York: Three Rivers Press.

Husin, M. M., Haron, R., \& Aziz, S. (2020). Adoption of financial technology in islamic crowd-funding: predicting small and medium-sized enterprises' intention to use the investment account platform. In Impact of Financial Technology (FinTech) on Islamic Finance and Financial Stability (pp. 12-35). IGI Global. 
Ibrahim, M. A., Fisol, M. W. \& Othman, Y. H. (2017). Customer intention on islamic home financing products: An application of theory of planned behaviour (tpb). Mediterranean Journal of Social Sciences, Rome-Italy, 8(2) 2-45.

Isah, M. A. (2010). Consolidation and financial performance. Doctoral Thesis, Bayero University, Kano Nigeria.

Islam, M. T., \& Khan, M. T. A. (2020). Inertia to the adoption of crowdfunding in Bangladesh: A study on start-up entrepreneurs. Cogent Business $\mathcal{E}$ Management, 7(1), 1811597.

Islam, M. T., \& Khan, M. T. A. (2019). Factors influencing the adoption of crowdfunding in Bangladesh: A study of start-up entrepreneurs. Information Development, 1-18. https://doi.org/10.1177/0266666919895554.

Kalanje, C. (2016). Enhancing the competitiveness and growth of SMES: Marketing challenges for SMEs. In 5th NASME International Conference and Exhibition.

Krejcie, R. V., \& Morgan, D. W. (1970). Determining sample size for research activities. Educational and Psychological Measurement, 30(1970), 607-610.

Mollick, E., \& Robb, A. (2016) Democratizing innovation and capital access: The role of crowdfunding. California Management Review, 58(2), 72-87.

Oseni, U. A. (2017). Toward a shariah compliant equity-based crowdfunding for the halal industry in Malaysia. International journal of Business and Society, 18(1), 223-240.

Owualah, S. L. (2017). Tackling youth unemployment through entrepreneurship. International Small Business Journal, 17(3), 49-59.

Perdana, F. F. P., Jan, M. T., Altunişik, R., Jaswir, I., \& Kartika, B. (2018). A research framework of the halal certification role in purchase intention of muslim consumers on the food products from muslim majority countries in the Middle East and North Africa. International Journal of Modern Trends in Business Research (IJMTBR), 1(2), 15 - 28.

Soreh, W. C. (2017). Awareness and attitude towards crowdfunding in Nigeria. International Journal of African and Asian Studies, 36(2017), 1-8.

Stone, M. (1974). Cross-validatory choice and assessment of statistical predictions. Journal of the Royal Statistical Society. Series B (Methodological), 36(2), 111-147.

Sulaeman, S., \& Ninglasari, S. Y. (2020). An empirical examination of factors influencing the behavioural intention to use zakat-based crowdfunding platform model for countering the adverse impact of covid-19 on MSMEs in Indonesia. In $4^{\text {th }}$ ICONZ International Conference of Zakat (ZakatTech for Inclusive Development) (pp. 203-218). October $7^{\text {th }}-8^{\text {th }}, 2020$, Jakarta, Indonesia: Center of Strategic Studies (PUSKAS) BAZNAS.

Thaker, M. A. B. M. T. (2018). Modelling SMEs' behavioral intention to adopt Islamic crowdfunding-small and medium enterprises (ICSMEs) model as a source of financing in Malaysia. Journal of Islamic Monetary Economics and Finance, 4(2), 293-310.

Wold, H. (1982). Soft modeling: The basic design and some extensions. In: Joreskog, K.G. and Wold, H.O.A., (Eds.). Systems under indirect observations: Part II, North-Holland, Amsterdam, 1-54.

World Bank (2016). An Assessment of the Private Sector in Nigeria. Washington www.spaajibade.com 